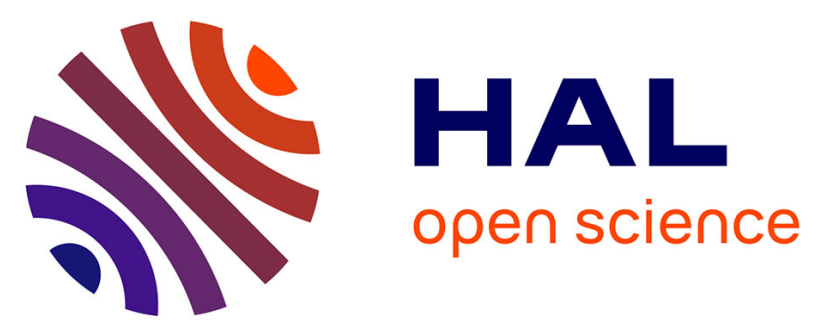

\title{
Description and bioecology of two new species of the genus Cryncus (Orthoptera, Gryllidae, Gryllinae) from Cameroon with a key and distribution map of all African species
}

Philene Corinne Aude Um Nyobe, Sevilor Kekeunou, Libin Ma, Tony Robillard, Alain Simeu-Noutchom, Charles Felix Bilong Bilong

\section{To cite this version:}

Philene Corinne Aude Um Nyobe, Sevilor Kekeunou, Libin Ma, Tony Robillard, Alain SimeuNoutchom, et al.. Description and bioecology of two new species of the genus Cryncus (Orthoptera, Gryllidae, Gryllinae) from Cameroon with a key and distribution map of all African species. Zootaxa, 2021, 4908 (4), pp.473-488. 10.11646/zootaxa.4908.4.2 . hal-03152982

\author{
HAL Id: hal-03152982 \\ https://hal.science/hal-03152982
}

Submitted on 26 Feb 2021

HAL is a multi-disciplinary open access archive for the deposit and dissemination of scientific research documents, whether they are published or not. The documents may come from teaching and research institutions in France or abroad, or from public or private research centers.
L'archive ouverte pluridisciplinaire HAL, est destinée au dépôt et à la diffusion de documents scientifiques de niveau recherche, publiés ou non, émanant des établissements d'enseignement et de recherche français ou étrangers, des laboratoires publics ou privés. 
Description and bioecology of two new species of the genus Cryncus (Orthoptera, Gryllidae, Gryllinae) from Cameroon with a key and distribution map of all African species

1. PHILENE CORINNE AUDE UM NYOBE ${ }^{1,} *$, phicoraude@yahoo.fr, https://orcid.org/0000-0002-7226-7877

2. SEVILOR KEKEUNOU ${ }^{1}$, skekeunou@gmail.com, https://orcid.org/0000-0002-9058$100 X$

3. LIBIN MA², libinma@snnu.edu.cn, https://orcid.org/0000-0002-8556-7158

4. TONY ROBILLARD ${ }^{3}$, tony.robillard@mnhn.fr, orcid.org/0000-0002-2177-9549

5. ALAIN SIMEU-NOUTCHOM ${ }^{1}$, simeunou@gmail.com, https://orcid.org/0000-0002$5386-9450$

6. CHARLES FELIX BILONG BILONG ${ }^{1}$, bilong_bilong@yahoo.com, https:// orcid.org/0000-0003-0138-5713

\footnotetext{
${ }^{1}$ University of Yaounde 1, Faculty of Science, Department of Animal Biology and Physiology, Cameroon.

${ }^{2}$ College of Life Sciences, Shaanxi Normal University, Xi'an, Shaanxi, 710119, China.

${ }^{3}$ Institut de Systématique, Evolution et Biodiversité (ISYEB), Muséum national d'Histoire naturelle, CNRS, SU, EPHE, UA, 57 rue Cuvier, CP 50, 75231 Paris Cedex 05, France.

*Corresponding author.
} 


\section{ABSTRACT}

The genus Cryncus Gorochov, 1983 composed of African crickets is reported for the first time in Cameroon by the description of two new species collected at Zamakoe, Ongot and Engout'Adjap in the southern Cameroonian plateau during an inventory study of crickets carried out from March 2014 to September 2015. These new species are: Cryncus camerounensis Um Nyobe, Kekeunou \& Bilong Bilong and Cryncus desutterae Um Nyobe, Kekeunou \& Ma. These descriptions bring the total number of species of this genus to 25. Cryncus camerounensis is distinguished by an irregularly shaped mirror, without a dividing vein, with a short apical field, while Cryncus desutterae is characterized by a divided oval mirror and a long apical field. Cryncus camerounensis was more abundant in the forest environment while Cryncus desutterae would exclusively colonize fallow land. This article is divided into two parts. The first part presents a description of the two new species, followed by a revised diagnosis of the genus Cryncus using both male and female characters and an identification key. The second part presents some bioecological data of these new species and a map of the geographical distribution of all known species of this genus.

Key words: Cryncus, Afrotropical region, Taxonomy, Distribution, Zamakoe.

\section{RESUME}

Le genre Cryncus Gorochov, 1983 composé de grillons africains est signalé pour la première fois au Cameroun par la description de deux nouvelles espèces collectées à Zamakoe, Ongot et Engout'Adjap dans le plateau sud camerounais durant une étude d'inventaire des grillons réalisée de mars 2014 à septembre 2015. Ces nouvelles espèces sont : Cryncus camerounensis Um Nyobe, Kekeunou \& Bilong Bilong et Cryncus desutterae Um Nyobe, Kekeunou \& Ma. Ces descriptions portent le nombre total d'espèces de ce genre à 25. Cryncus camerounensis se distingue par un miroir de forme irrégulière, sans veine de division, avec un champ apical court alors que Cryncus desutterae se caractérise par un miroir ovale divisé et un champ apical long. Cryncus camerounensis a été plus abondant en milieu forestier alors que Cryncus desutterae coloniserait exclusivement les jachères. Cet article est divisé en deux parties. La première partie présente la description des deux nouvelles espèces, suivie d'une diagnose révisée du genre Cryncus utilisant à la fois des caractères des mâles et des femelles et d'une clé d'identification. La deuxième partie présente quelques données bioécologiques de ces nouvelles espèces et une carte de la répartition géographique de toutes les espèces connues de ce genre.

Mots clés: Cryncus, Afrotropical region, Taxonomy, Distribution, Zamakoe. 


\section{Introduction}

Biological diversity, a driving functioning of the ecosystems, remains badly known still nowadays, especially for groups of insects which are not emblematic. Crickets (Grylloidea), which count approximately 4,500 species, live for the majority in tropical area and are diversified particularly in wet tropical zone (Chopard 1965). The composition of their settlements is strongly influenced by the environments (savannah, field, fallow, forest), their rhythms of life and their ecological preferences (Chiffaud-Mestre \& Gillon 1984). Given the accelerated rhythm of conversion of forests into grassy vegetations in the world, the study of biological diversity of crickets is essential in order to have a knowledge pushed on these latter.

The genus Cryncus Gorochov, 1983 is currently known only from the African continent. Gorochov (1983, 1990) described seven species of Cryncus and five others transferred from Gryllopsis (Chopard 1934, 1935, 1939, 1967), all being found in West, East and North Africa. Otte (1985) also transferred one additional species from Gryllopsis and described nine others from South and East Africa. Nowadays, the genus Cryncus encompasses twenty-three species with records in Egypt, Zambia, Burkina, Democratic Republic of Congo, Sierra Leone, Ghana, Djibouti, Tanzania, Kenya and Ethiopia (Orthoptera Species File online). Prior to the current work, Cryncus has been only reported in one country of Central Africa (Democratic Republic of Congo). We report its presence for the first time in Cameroon. The morphology of East African Cryncus spp. is very similar; they can only be reliably distinguished by the male songs (Otte 1985). According to Otte (1985), all of them might have been treated as a single species if their songs had not been known. In addition, Cryncus pugu Otte, 1985 is only recognizable by its song until its formal morphological description. However, Desutter-Grandcolas et al. (2018) have shown limits in the use of acoustic data to formally describe new taxa by the sole acoustic productions of unseen specimens, forcing a 'sound-based taxonomy' on traditional taxonomy, hence the interest in taxonomy of associating morphological description and bioacoustics. Besides, morphological and bioecological data remain essential in the taxonomy of ensiferans (Simeu-Noutchom et al. 2020). The aim of this work is to update the taxonomic, bioecological and biogeographical knowledge of Cryncus through the description of two new species from Cameroon.

\section{Materials and Methods}

Sampling localities. Specimens studied were sampled in habitats with different levels of anthropisation (Table 1) defined according to the benchmark by Gockowski (1996). 
Table 1: Characteristics of the Benchmarck village blocks (modified from Gockowski, 1996)

Sampling was carried out in Zamakoe, Ongot and Engout'Adjap (Fig.1) in two types of vegetation: closed (forests) and open environments (fallows). The southern Cameroonian forest is dominated by Sterculiaceae and Ulmacae; its undergrowth is made up of herbaceous plants such as Maranthaceae and Acanthaceae (Westphal et al. 1981). In this area, the natural vegetation is regularly degraded by the economic exploitation of wood and the practice of slashand-burn agriculture (Santoir \& Bopda 1995). The resulting bushy vegetation after degradation is less diversifed and dominated by Chromolaena odorata, Ageratum conizoides, Synedrella nodiflora, and Imperata cylindrica. Plantain, cassava, yam, maize, and groundnut are the main food crops, while industrial ones include cocoa, coffee, sweet banana, and palm oil (Westphal et al. 1981; Oumarou et al. 2020). The southern Cameroon plateau has an equatorial climate type with four seasons, including a long dry season (LDS) from mid-November to mid-March, a short rainy season (SRS) from mid-March to June, a short dry season (SDS) from July to midSeptember, and a long rainy season (LRS) from mid-September to mid-November (Suchel 1988). Precipitations range from 1500-2000 mm per year (Amou'ou et al. 1985; Santoir \& Bopda 1995). The average annual rainfall is $1510 \mathrm{~mm}, 1643 \mathrm{~mm}$ and $1820 \mathrm{~mm}$ in Ongot, Zamakoe and Engout'Adjap respectively (Kekeunou et al. 2006). Average annual temperature is high (between 25 to $27^{\circ} \mathrm{C}$ ) outside the forest canopy; under forest cover, temperature is low and humidity is constantly high (Suchel 1988). Soils are "Xanthic" or "Plinthic Ferralsols" (IUSS Working Group WRB 2015) and belong to the group of ferralitic soils strongly desaturated. There are clay soils from yellowish brown to bright brown, with $\mathrm{pH}$ generally acidic, very poorly drained hydromorphic soils in the shallows (Robain 1998).

Figure 1. Location of the sampling localities.

Sampling methods. Crickets were sampled once per month in each study locality, from March 2014 to September 2015 in closed (secondary or tertiary forests) and open (fallows and / or mixed crop fields) environments, using quadrats and pitfall traps. During the sampling process, 22 mobile quadrats and 10 pitfall traps distributed along 2 transects of $110 \mathrm{~m}$ each one, have been put randomly in each type of vegetation. The quadrats of $1 \mathrm{~m}^{2}$ were spaced from each other by a distance of $10 \mathrm{~m}$. Each one was entirely excavated from litter to $5 \mathrm{~cm}$ depth in the ground. Crickets were captured during the sampling day with the wipe net, the hand or with a mouth vacuum cleaner, then were kept in labeled boxes containing $70 \%$ ethanol for later identification. Pitfall traps were made up of plastic cups $(8 \mathrm{~cm}$ diameter and $12 \mathrm{~cm}$ deep) buried in the ground 
level and containing 5\% formalin as preservative. Crickets captured by the pitfalls were collected a month later, transferred into labeled boxes, rinsed with water then stored in $70 \%$ ethanol in the same boxes.

Study material. Observations of morphological characters were performed using a binocular magnifier Leica connected to an Amscope camera (Heerbrugg brand). The identifications were done by comparison with original species descriptions. The pictures of external morphology (Figs. 2 A-F and 3 A-F) were taken with specimens immersed in 70\% ethanol, using a LCD Digital Microscope connected to a computer via USB cable. Drawings (Figs. 2 G-I and 3 G-I) were made by CorelDRAW $\times 8$ software, while measurements were taken using a NEIKO electronic caliper. The maps of the study localities and species distribution were built with the software QGIS 2.2.0. Figure 4, representing the abundances of the species according to the type of vegetation, was realized using the software R 4.0.2 (R Core Team 2017).

Dissection of the phallic complex. Dissection of adult male's phallic complex was performed on specimens preserved in 70\% ethanol, using dissection-tools and a binocular magnifier Leica. The male genitalia were dissected by making a small slit between paraproct and subgenital plate. The isolated phallic complex was kept in a $5 \% \mathrm{KOH}$ solution for 8 hours in an eppendoff tube in order to clear it. This organ was then immersed in distilled water for about 5 minutes, then in ethanoic acid for 30 minutes to neutralize the $\mathrm{KOH}$ solution, and finally in $1 \%$ fuchsine solution for 30 minutes to stain the sclerotized parts before observation.

Data analysis. Data were analyzed using Excel version 2010 and PAST version 3.2. These softwares allowed to: (1) calculate averages of measurements and standard errors; (2) verify the normality of distributions of quantitative variables by the Shapiro-Wilk test; (3) compare the means of measurements by the Student's test in case of normality and homoscedacity; (4) compare means of measurements using Mann-Withney test in absence of normality; (5) calculate the frequency of occurrence (FO) of each species (FO $\geq 50 \%$ : constant species; $25 \%$ $\leq$ FO $<50 \%$ : accessory species; FO $<25 \%$ : accidental species). All tests values were considered significant for $\mathrm{P}<0.05$. In tables 5 and 6 , values preceding parentheses represent the number of sampling campaigns during which species was captured; those in parentheses represent frequency of occurrence obtained by the ratio between the number of descents where a species was present over the total number of descents in the field (Dajoz 1985). 


\section{Abbreviations used in morphological identification:}

General morphology: FI, FII, FIII, fore, median, hind femora; FW, forewing; TI, TII, TIII, fore, median, hindtibia.

Terminology of forewing venation is according to Desutter-Grandcolas et al. (2017) as follows: cu.v., cubital vein; m.v., median vein; r.v., radial vein; sc.v., subcostal vein and its branches; o.v., oblique vein; d.v., diagonal vein; a.n., anal node; m., mirror; $h .$, harp; $c$. , cord; a.f., anal field; ap.f., apical field; l.f.,lateral field.

\section{Abbreviations used for the measurements (mm):}

Measurements were done in reference to Otte (1985): BL, body length; FL, hind femora length; TL, hindtibia length; FWL, forewing length; PL, pronotal length; ML, Mirror length; MW, Width of the mirror; OL, ovipositor length; CL, cercal length.

\section{Abbreviations used in genitalia identification:}

Terminology for genitalia is according to Desutter (1987) and Desutter-Grandcolas (2003) as follows: Ect.Ap., ectophallic apodeme; Ect.F., ectophallic fold; M.Lophi, median lophi; L.Lophi, lateral lophi; PsP, pseudepiphallic paramere; R, ramus.

\section{Results}

\section{Systematic part}

Order ORTHOPTERA Olivier, 1789

Suborder ENSIFERA Chopard, 1920

Infraorder GRYLLIDEA Laicharting, 1781

Superfamily GRYLLOIDEA Laicharting, 1781

Family GRYLLIDAE Laicharting, 1781

Subfamily GRYLLINAE Laicharting, 1781

Genus Cryncus Gorochov, 1983

Type species: Cryncus olsufievi Gorochov, 1983

\section{Cryncus camerounensis Um Nyobe, Kekeunou \& Bilong Bilong sp. nov.}

Material examined. Holotype: male, CAMEROON, Center Region, Zamakoe $\left(3^{\circ} 33^{\prime} 816^{\prime \prime} \mathrm{N}\right.$, 11³1'913"E), secondary forest, 21/iii/2015; pitfall trap; P. Um Nyobe \& team leg. (MNHN_EO_ENSIF1139).

Paratypes:5 males, 14 females, CAMEROON, Center Region, Zamakoe ( $3^{\circ} 33^{\prime} 816^{\prime \prime} \mathrm{N}$, $\left.11^{\circ} 31^{\prime} 913 " \mathrm{H}\right)$; principally in secondary forest, only two females in crops field (14/iii/2015, 16/ii/2015, 18/iv/2015, 21/iii/2015); pitfall trap mainly, quadrat trap occasionally (MNHN_EO_ENSIF10950-10968). 1 female, CAMEROON, Center Region, Ongot ( $3^{\circ} 85^{\prime} 786$ "N,

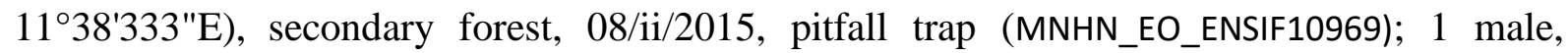


CAMEROON, South Region, Engout'Adjap ( $\left.2^{\circ} 42^{\prime} \mathrm{N}, 11^{\circ} 03^{\prime} \mathrm{E}\right)$, secondary forest, 09/06/2015, pitfall trap; P. Um Nyobe \& team leg. (MNHN_EO_ENSIF10970).

Etymology. Epithet camerounensis refers to the country where the type material was found.

Diagnosis. Micropterous species with forewings reaching abdomen mid-length. Mirror of irregular shape, wider than long, without division and presenting a space between it and the apical field which is short (Fig. 2 C, G). Presence of an elongated oval tympanum on outer surface of anterior tibia; inner face without tympana. Posterior tibia with 5 dorsal spurs on each side (internal and external). Median lophi and ectophallic fold absent (Fig. 2 H, I). Ectoparameres long, tapered and reaching apical end of epiphallic lobes without exceeding them (Fig. 2 H, I).

Figure 2. Morphology of Cryncus camerounensis sp. nov.: (A) male head and pronotum, (B) male lateral view of head and pronotum, (C) male forewing, (D) female head and pronotum, (E) female lateral view of head and pronotum, $(\mathrm{F})$ female fore wing, $(\mathrm{G})$ male forewing drawing, $(\mathrm{H})$ male genitalia drawing in dorsal view, (I) male genitalia drawing in ventral view. Scale bars: A: $7 \mathrm{~mm}$; B, C, E: 5 mm; D, 8 mm;F, 11 mm; G, 5 mm; H, I, $500 \mu \mathrm{m}$.

Description. (Fig. 2 A-I; Table 2)

Male. Head: presence of a pale brown interantennary stripe extending dorsally under each eye to terminal end of occiput, defining a nearly rounded black area containing two short pale brown lines on occiput. Short brown line posterior to eye (Fig. 2 A). Face with a black band above epistomal suture; cheeks black posterior to eye but pale brown below eye (Fig. 2 B). Pronotum: dorsum pale brown, with numerous small dark spots; lateral lobes with pale band in lower third (Fig. 2 A). Forewings: grayish brown on dorsal and lateral fields; veins dark brown; harp with 4 oblique veins; mirror of irregular shape, without division, and connected to first cord by two veinlets; mirror connected to the apical field only at its right end creating a space that separates them; presence of two cords strongly curved inwardly the elytra, and an outermost cord straight; apical field short, with irregularly shaped cells (Fig. 2 C, G). Hind wing vestigial under forewings. Abdomen: dorsum of abdomen dark brown, but with rows of light patches; venter pale. Cerci pale brown. Legs: front and middle legs: femora pale with dark spots on dorsum and sometimes with large dark patches on inner and outer faces; anterior tibia with two pale bands in basal half and one at distal end with large oval tympanum present on outer face; inner face without tympana; fore tibia with 6 and mid tibia with 2 apical spurs. Hind femora: pale in background, with dark pubescence; on lateral face dark pubescence usually arranged in oblique rows; femora darker around knees. Hind tibia: length 0.58 times length of femora; with 5 inner 
and 5 outer subapical spurs. Cerci: pale brown; length 0.66 times as long as hind femora. Male genitalia: epiphallus bilobed; lobes pointed with U-shaped depression between them; ectoparameres long, tapered and reaching the apical end of the epiphallic lobes without exceeding them (Fig. 2 H, I). Female. Same characteristics as male except forewings, micropterous but truncated at their terminal end (Fig. 2 D, F). Forewings triangular, not overlapping at midline. Hindwings missing. Ovipositor: length 0.86 to 1.2 times the length of hind femora (Table 2).

Male holotype measurements: BL, $14.84 \mathrm{~mm}$; PL, $2.46 \mathrm{~mm}$; PW, $3.72 \mathrm{~mm}$; FWL, $7.60 \mathrm{~mm}$; ML, 2.92 mm; MW, 1.53 mm; CL, 6.68 mm; FL, 10.12 mm; FW, 3.32 mm; TL, 5.87 mm. File with 238 teeth.

Table 2. Cryncus camerounensis sp. nov. measurements in millimeters: average \pm standard error (minimum-maximun) number of specimens studied

Remarks. Cryncus camerounensis sp. nov. differs from other species of the genus by its mirror which is only connected to the apical field on the right lateral side, making a rather noticeable gap between the mirror and the apical field. C. camerounensis sp. nov. is similar to Cryncus duplicatus Otte, 1985 and Cryncus impiger Otte, 1985 by the structure of the occiput and pronotum but, it differs from these species by the forewing and genitalic structures. $C$. duplicatus and $C$. impiger have 5 oblique veins and broad ectoparameres while $C$. camerounensis has 4 oblique veins with tapered ectoparameres.

\section{Cryncus desutterae Um Nyobe, Kekeunou \& Ma sp. nov.}

Material examined. Holotype: male, CAMEROON, Center Region, Zamakoe ( $3^{\circ} 33^{\prime} 816^{\prime \prime N}$, 11³1'913"E), in crops field, 20/vi/2015; pitfall trap; P. Um Nyobe \& team leg. (MNHN_EO_ENSIF10971).

Paratypes:1 male, 2 females, CAMEROON, Center Region, Zamakoe (333'816"N, 11³1'913"E); all in crops field, 20/vi/2015, pitfall trap exclusively (MNHN_EO_ENSIF10972ENSIF10974).

1 male, 2 females, CAMEROON, Ongot ( $\left.3^{\circ} 85^{\prime} 786 " \mathrm{~N}, 11^{\circ} 38^{\prime} 333^{\prime \prime E}\right)$; all in crops field, (25/vii/2015, 20/xii/2014), pitfall trap exclusively; P. Um Nyobe \& team leg. (MNHN_EO_ENSIF10975-ENSIF10977).

Etymology. Cryncus desutterae Um Nyobe, Kekeunou \& Ma sp. nov. is dedicated to Laure Desutter-Grandcolas for her background work on the taxonomy of crickets. 
Diagnosis. Brachypterous species with forewings covering almost the entire abdomen with a long apical field and an oval mirror with a dividing vein (Fig. $3 \mathrm{C}, \mathrm{G})$. Anterior tibia with two tympana: one small, round and internal, the other oval and elongated on external face. Hind tibia brownish with 5 dorsal spurs on the internal face and 6 dorsal spurs on the external face. The first spur on the outer side very small. Median lophi tends to disappear and the ectophallic fold little individualized. Ectoparameres short, very large and do not reach the apical end of epiphallic lobes (Fig. 3 H, I).

Figure 3. Morphology of Cryncus desutterae sp. nov.: (A) male head and pronotum, (B) male lateral view of head and pronotum, (C) male fore wing, (D) female head and pronotum, (E) female lateral view of head and pronotum, $(F)$ female forewing, $(\mathrm{G})$ male forewing drawing, $(\mathrm{H})$ male genitalia drawing in dorsal view, (I) male genitalia drawing in ventral view. Scale bars: A, $9 \mathrm{~mm}$; B, 8 mm; C, 5 mm; D, F: 7 mm; E, 6 mm; H, I, $500 \mu \mathrm{m}$.

\section{Description. (Fig. 3 A-I; Table 3)}

Male. Head: Occiput with 3 brown dark bands, two short lateral ones posterior to eyes and a long median one extending up to interantennial space and presenting a light brown line at its middle (Fig. 3 A, D). Face speckled above epistomal suture and below level of antennae; cheeks black posterior to eye but pale brown below eye (Fig. 3 B). Pronotum: dorsum pale brown, with numerous small dark spots; lateral lobes with two pale spots (Fig. 3 A). Forewings: grayish brown on dorsal and lateral fields; veins dark brown; harp with 4 oblique veins; oval mirror with a dividing vein and connected to the first cord by two veinlets; presence of two cords weakly curved inwardly the elytra and one outermost cord straight; long apical field, with rectangular and triangular shaped cells (Fig. 3 C, G). Hindwings missing. Abdomen: dorsum of abdomen dark brown with rows of light patches; venter pale. Cerci pale brown. Legs: front and middle legs: femora pale with dark spots on dorsum and sometimes with large dark patches on inner and outer faces; tibia with two pale bands in basal half and one at distal end with large outer and a tiny inner tympanum; fore tibia with 6 and mid tibia with 2 apical spurs. Hind femora: pale in background with dark pubescence; on lateral face dark pubescence usually arranged in oblique rows; femora darker around knees. Hind tibia: length 0.69 times length of femora with 5 inner and 6 outer subapical spurs. Cerci: pale brown broken. Male genitalia: epiphallus bilobed; lobes pointed with U-shaped depression between them; ectoparameres short, very large not reaching the apical end of the epiphallic lobes (Fig. 3 H, I). Female. Same characteristics as male except forewings slightly exceeding half of the abdomen. There is a variation in coloration in females concerning the color of occiput and pronotum: some present 
brown or black bands. Hindwings missing. Ovipositor: length 0.94 to 1.33 times length of hind femora (Table 3).

Male holotype's measurements: BL, 12.09 mm; PL, $1.57 \mathrm{~mm}$; PW, $2.70 \mathrm{~mm}$; FWL, $7.49 \mathrm{~mm}$; ML, $2.67 \mathrm{~mm}$; MW, $1.69 \mathrm{~mm}$; FL, $7.21 \mathrm{~mm}$; FW, $2.86 \mathrm{~mm}$; TL, $4.99 \mathrm{~mm}$. File with 261 teeth.

Table 3. Cryncus desutterae sp. nov. measurements in millimeters: average \pm standard error (minimummaximun) number of specimens studied.

Remarks. The comparison of the forewing characters in male Cryncus shows through the FWL / PL ratio that Cryncus desutterae sp. nov. has the longest forewings, followed by Cryncus grumeti Otte, 1985 with 4.77 and 3.18 respectively (Otte 1985; Gorochov 1983, 1990). C. desutterae sp. nov. is similar to $C$. grumeti by the structure of the occiput, pronotum and forewings, but differs from it by the length of the ectoparameres which are long, broad and extend beyond the apical end of the epiphallic lobes in $C$. grumeti.

Revised Cryncus diagnosis. Vertex and occiput totally black or with 3 brown dark or black bands. Presence of one or two tympana on anterior tibia. Harp with 3 to 5 oblique veins. Apical field of elytra shorter or longer than the mirror. Female forewings short, triangular, not overlapping at the midline, or relatively long, slightly exceeding the abdominal half and partly overlapping in the middle. Hindwings absent or reduced to wing stumps. Hind tibia with a characteristic small pale patch at its distal end and having 5 dorsal spurs on the inner side and 5 or 6 dorsal spurs on the outer side. Epiphallus covered with bristles at its apical end. Median lophi tending to disappear in most species, ectophallic fold eventually present, very well or little individualized or totally absent.

\section{Key for the species of Cryncus}

This key is produced from morphological characters and excludes $C$. pugu which is only known by its song.

1a. Mirror absent. C. massarti.

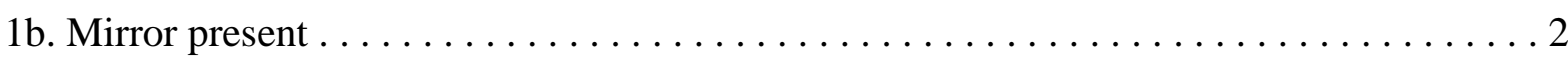

2a. Fore wings with 3 oblique veins $\ldots \ldots \ldots \ldots \ldots \ldots \ldots \ldots \ldots \ldots \ldots \ldots \ldots \ldots \ldots \ldots \ldots \ldots$ p phellus.

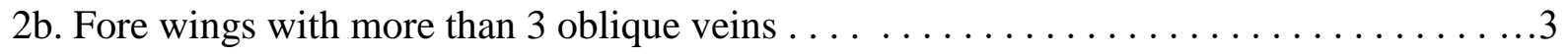

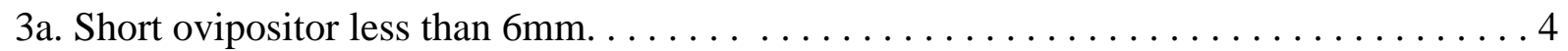

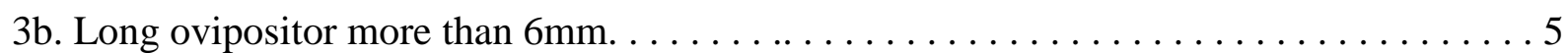

4a. Very short ovipositor $(1,3 \mathrm{~mm}) . \ldots \ldots \ldots \ldots \ldots \ldots \ldots \ldots \ldots \ldots \ldots \ldots \ldots \ldots \ldots$ dmitrievi. 
4b. Short ovipositor (4-4.5 mm). C. olsufievi.

5a. Anterior tibia with a large oval tympanum on outer face, and a small round tympanum on inner face.

5b. Anterior tibia with a large oval tympanum on outer face, and inner face without tympana...

6a. Hind tibia with 5 inner and 6 outer subapical spurs C. saussurei.

6b. Hind tibia with 5 inner and 5 outer subapical spurs. C. camerounensis sp. nov.

7a. Pronotum pale brown and unspotted. . C. scenicus.

7b. Pronotum pale brown spotted .8

8a. Presence of 4 dark prominent points along the posterior edge of the pronotum and lateral lobes completely black. . . . . . . . . . . . . . . . . . . . . . . . .

8 b. Presence of small dark dots on pronotum and lateral lobes with pale band in lower third......

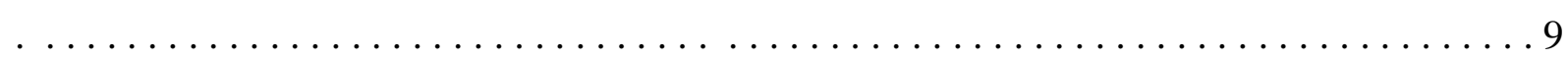

9a. Long ectoparameres extending beyond the apical end of the epiphallic lobes.... C. grumeti. 9b. Short ectoparameres not reaching the apical end of the epiphallic lobes.... 10

10a. Male genitalia with short endoparameres, and short tapering ectoparameres. . C. gambelae. 10b. Male genitalia with long endoparameres, and short wide ectoparameres. . . . . . 11 11a. Species less than $12 \mathrm{~mm}$ in size with an apical field of medium length. .... C. illubabori. 11b. Species larger than $12 \mathrm{~mm}$ with a long apical field.

12a. Ectoparameres with pointed ends . . . C. medvedevi.

12b. Ectoparameres with rounded ends. .13

13a. Pronotum strongly narrowed in front, macropterous female. C. apricus.

13b. Pronotum not narrowed in front, brachypterous or micropterous female. .14

14a. Occiput with 3 black bands, the median one being wider, long and the lateral bands narrower, shorter. C. desutterae sp. nov. 14b. Occiput with back zone delimited by brown bands extending laterally under each eye to

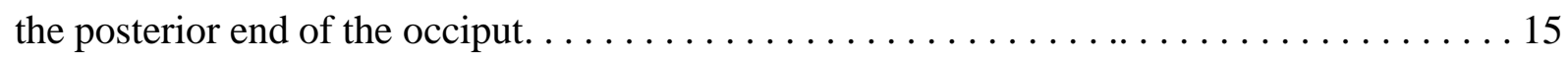
15a. Forewings with a mirror with a dividing vein. $\ldots \ldots \ldots \ldots \ldots \ldots \ldots \ldots \ldots \ldots \ldots \ldots \ldots \ldots$ 15b. Forewings with a mirror without a dividing vein. . . . . . . . . . . . . . 19 16a. Male forewings with 4 oblique veins. . . . . . . . . . . . . . . . . 17

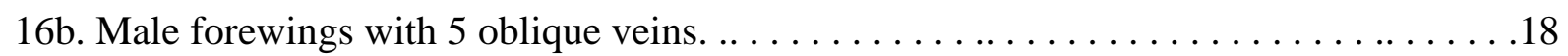
17a. Occiput with 2 brownish stripes in the black area forming the letter H; Pronotum with many black spots and dots. C. alternatus. 
17b. Occiput with 3 short brownish stripes in the black area; Pronotum spotted by a few black

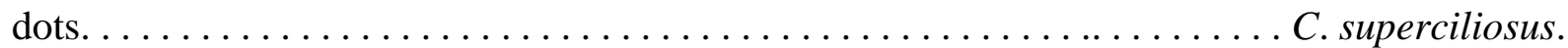

18a. Division of vein forming a circle with the mirror. ............. matuga.

18b. Division of vein forming a triangle with the mirror. .............. agilis.

19a. Two broad yellowish bands extending from the head to the tip of the abdomen.. . . . . . C. bifasciatus.

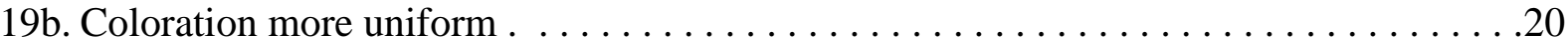

20a. Mirror with a short vein indicating the start of division. $\ldots \ldots \ldots \ldots \ldots \ldots \ldots \ldots \ldots$

20b. Mirror without a short vein to indicate the beginning of division. . . . . . . . 22

21a. Male forewings with 4 oblique veins. ................... duplicatus.

21b. Male forewings with 5 oblique veins. . . . . . . . . . . . . . . . . . C. mombo.

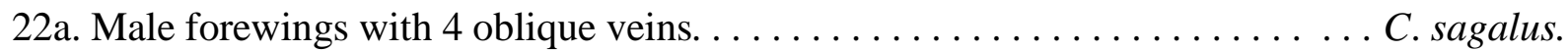

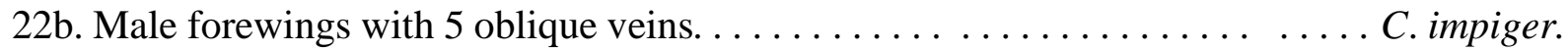

Bioecology. (Fig. 4; Tables 4 and 5)

During 19 months of sampling in the three study localities, 19 specimens of Cryncus camerounensis were captured in forests and 2 others in fallows with a peaks of abundance in March and April 2015; as for Cryncus desutterae, only 6 individuals were captured in Zamakoe and Ongot exclusively in fallows (Fig. 4).

Figure 4. Numeric temporal fluctuations of Cryncus camerounensis sp. nov. and Cryncus desutterae sp. nov. in forests and fallows of southern Cameroon plateau.

Cryncus camerounensis was accessory $(\mathrm{FO}=26.32 \%)$ in forests and accidental in fallows $(\mathrm{FO}=5.26 \%)$; while $C$. desutterae, although it was found exclusively in fallows, it remained accidental $(\mathrm{FO}=15.78 \%)$, see table 4 .

TABLE 4. Frequencies of occurrence of Cryncus camerounensis sp. nov. and Cryncus desutterae sp. nov. as a function of the types of vegetation and localities.

Cryncus camerounensis was also captured with pitfalls $(\mathrm{FO}=26.32 \%)$ and accidentally with quadrats $(\mathrm{FO}=5.26 \%)$; while $C$. desutterae was accidentally and only captured $(\mathrm{FO}=$ $15.78 \%$ ) with pitfalls. In general, pitfalls allowed to sample the majority of specimens, see table 5. 
TABLE 5. Frequencies of occurrence of Cryncus camerounensis sp. nov. and Cryncus desutterae sp. nov. depending on the capture methods and localities.

\section{Geographical distribution of Cryncus spp. and their type localities}

All Cryncus spp. known to date are found mostly in the intertropical zone of the African continent (Fig.5).

Figure 5. Distribution map of African species of the genus Cryncus.

Below is listed the type locality of each species:

1. C. apricus (Saussure, 1877)

Type locality: Africa, Northern Africa, Egypt

2. C. saussurei Otte, 1985

Type locality: Africa, South Tropical Africa, Zambia, Luano Valley, Mulungushi

3. C. olsuflevi Gorochov, 1983

Type locality: Africa, West Tropical Africa, Burkina, Poundou

4. C. bifasciatus (Chopard, 1939)

Type locality: Africa, West-Central Tropical Africa, Democratic Republic of Congo (RDC), Katanga: Kipala-Kisinga

5. C. massarti (Chopard, 1934)

Type locality: Africa, West-Central Tropical Africa, Democratic Republic of Congo, Lomani: Kamina 6. C. notabilis (Walker, 1869)

Type locality: Africa, West Tropical Africa, Sierra Leone

7. C. dmitrievi Gorochov, 1983

Type locality: Africa, Northeast Tropical Africa, Djibouti, Djildessa-Djibuti

8. C. scenicus (Gerstaecker, 1869)

Type locality: Africa, East Tropical Africa, Tanzania, Jipe Lake

9. C. duplicatus Otte, 1985

Type locality: Africa, East Tropical Africa, Tanzania, Ngorongoro Crater

10. C. superciliosus (Sjostedt, 1909)

Type locality: Africa, East Tropical Africa, Tanzania, Ngare na nyuki.

11. C. pugu Otte, 1985

Type locality: Africa, East Tropical Africa, Tanzania, Pugu Hills outside of Dares Salaam

12. C. mombo Otte, 1985

Type locality: Africa, East Tropical Africa, Tanzania, Mombo

13. C. grumeti Otte, 1985

Type locality: Africa, East Tropical Africa, Tanzania, Serengeti Plains, Grumeti River, Kirawira

14. C. agilis Otte, 1985

Type locality: Africa, East Tropical Africa, Tanzania, Manyara National Park, woodland at N end of lake

15. C. alternatus Otte, 1985

Type locality: Africa, East Tropical Africa, Kenya, Matuga

16. C. impiger Otte, 1985

Type locality: Africa, East Tropical Africa, Kenya, Nairobi

17. C. sagalus Otte, 1985

Type locality: Africa, East Tropical Africa, Kenya, Matuga

18. C. matuga Otte, 1985

Type locality: Africa, East Tropical Africa, Kenya, Matuga

19. C. gambelae Gorochov, 1990 
Type locality: Africa, Northeast Tropical Africa, Ethiopia

20. C. illubabori Gorochov, 1990

Type locality: Africa, Northeast Tropical Africa, Ethiopia

21. C. medvedevi Gorochov, 1990

Type locality: Africa, Northeast Tropical Africa, Ethiopia

22. C. pulchellus Gorochov, 1990

Type locality: Africa, Northeast Tropical Africa, Ethiopia

23. C. rybalovi Gorochov, 1990

Type locality: Africa, Northeast Tropical Africa, Ethiopia

24. C. camerounensis Um Nyobe, Kekeunou \& Bilong Bilong sp. nov.

Type locality: Africa, Central Africa, Cameroon

25. C. desutterae Um Nyobe, Kekeunou \& Ma sp. nov.

Type locality: Africa, Central Africa, Cameroon

\section{Discussion}

The present study shows that Cryncus is present in Cameroon, and represented by Cryncus camerounensis Um Nyobe, Kekeunou \& Bilong Bilong sp. nov. and Cryncus desutterae Um Nyobe, Kekeunou \& Ma sp. nov. Both species differ morphologically from each other and from other Cryncus species by the structure of the occiput, pronotum, forewings and male genitalia. From the occiput pattern, Cryncus can be divided into two groups. The first one is made up of species having two pale gray-brown fine bands (one short and one long), extending laterally under each eye to the posterior end of the head delimiting the vertex and the occiput completely black. It is the case of $C$. camerounensis, $C$. scenicus, $C$. grumeti, $C$. gambelae, C. medvedevi, C. sagalus, C. superciliosus, C. alternatus, C. bifasciatus, C. duplicatus, C. impiger, C. matuga, C. saussurei, C. agilis, C. mombo, C. episcopus. The second one is composed of species having three pale gray-brown to black bands starting from the terminal end of the occiput to the anterior end of the vertex (the median being wider and longer than lateral bands gradually narrowing from the posterior to the anterior part). It is the case of C. desutterae, C. illubabori, C. rybalovi, C. pulchellus, C. olsufievi, C. dmitrievi, C. apricus, C. notabilis, $C$. massarti. The shapes and sizes of these bands make it possible to distinguish the species (Otte 1985). The particularity of C. camerounensis and C. desutterae is their pale brown pronotum spotted with a few small black dots. By this character, they are distinguishable from C. scenicus with an unspotted pronotum, C. superciliosus whose pronotum has numerous black dots and spots, and C. bifasciatus with two wide ivory bands on pronotum extending from antennae on cerci. According to Otte (1985) the apical area is usually shorter than mirror, but in $C$. desutterae sp. nov. the apical area is longer than the mirror; so, depending on the species, the apical area can be shorter or longer than the mirror. Based on Otte (1985) and Gorochov (1983, 1990), we hypothesize that all species without a divided mirror have a short apical field while those with a divided mirror have a long apical field. We also noticed that $C$. massarti, the 
only known species without mirror, has a long apical field. All species of Cryncus have either four or five oblique veins in the harp (usually four as mentioned by Otte (1985)). C. pulchellus is the only species which has only three oblique veins. Besides, $C$. camerounensis and $C$. desutterae have more teeth on the stridulatory file than the others species of the genus, with respectively 238 and 261 teeth. The ML / MW ratio shows that the new species have the longest mirrors with ratios of 1.71 and 1.58 respectively. Concerning females, those of $C$. desutterae also present longer forewings, with a ratio of 2.88. Female forewings are variable as mentioned by Otte (1985), since two West African species have wings about twice as long as the pronotum and partly overlapping in the middle, while wings are generally triangular, do not overlap at the midline, and are 1.0 to 1.5 as long as the pronotum length in species from East Africa. The new species presented in this work, which belong to central Africa, we observed the presence of these two wing types. The OL / FL ratio for all species shows that the posterior femora are as long as the ovipositor; except for C. olsuflevi Gorochov, 1983 and C. dmitrievi Gorochov, 1983 which have very short ovipositor (Gorochov 1983).

The concentration of Cryncus spp. in the intertropical zone could reflect a larger sampling effort in this zone. In other words, the lack of data concerning these species in some African countries could be due to the absence of sampling, or to a real absence of these species in these countries.

Cryncus spp. are entirely flightless; the east African species are commonly found in leaf litter in woodlands or in thick grasses at the edges of lowland forests (Otte 1985). Since the frequency of occurrence of $C$. camerounensis sp. nov. is $(26.32 \%<50 \%)$ in forests and in fallows $(<25 \%)$, its preferred habitat probably corresponds to the forest. C. desutterae sp. nov. would prefer more open environments, since it was only captured in fallows with a frequency of occurrence $<25 \%$, which attests that it is accidental. A more increased sampling effort could provide a better idea of the habitat of these two species. Most individuals were captured by pitfalls and, this method seems more suitable to catch crickets. Chiffaud \& Gillon (1985) reported that the quadrat sampling method leads to an underestimation of abundances in the case of small species, early stages of crickets, and individuals that take refuge in burrows. However, since our study was carried out during the day, when crickets are generally inactive, it would be interesting to consider captures in the quadrats in the half-light, which corresponds to the moment when crickets are more active (Chiffaud \& Gillon 1985) to effectively compare this method to that of the pitfalls.

\section{Acknowledgements}


The authors thank Professor A.V. Gorochov from the Zoological Institute, Russian Academy of Sciences, for his expertise in Cryncus species determination of this study.

\section{References}

Amou'ou, J.P., Melingui, A., Mounkam, J. \& Tchepannou, A. (1985) Le Cameroun. Armand Colin, Editions Clé, Paris. 127p.

Chiffaud, J. \& Gillon, Y. (1984) Relations entre niche trophique et habitat chez un peuplement de grillons en mosaïque forêt-savane (Lamto, Côte-d'Ivoire). - Acta Oecologica, Oecol Getier, 5 (1), 53-62.

Chiffaud, J. \& Gillon, Y. (1985) Traits généraux et composition du peuplement des grillons de la savane de Lamto (Côte-d'ivoire) brûlée et non brûlée (orthoptera, gryllidae). Annales de la Société entomologique de France, New Series, 21 (3), 307-316.

Chopard, L. (1934) Catalogues raisonnes de la faune entomologique de Congo Belge. Orthoptères Gryllides. Annales du Musée du Congo Belge, Tervuren. Zoologie. Série 3, Section II, Tome IV, fascicule $1: 1-88$.

Chopard, L. (1935) Contributions à 1'étude de la Faune du Mozambique. Voyage de M. P. Lesne (1928-1929). Orthoptères Ensifères. Memórias Museu Zoológico da Universidade de Coimbra, série I, no. 85 : 13-32.

Chopard, L. (1939) Gryllidae. Parc National Albert. I. Mission G. F. de Witte, 1933-1935. Fascicule 27(2), 5-15.

Chopard L. (1965) Orthoptéres et Aptérygotes de France. Ed.N.Boubéd et C ${ }^{\mathrm{ie}}$.Paris, pp. 4689.

Chopard, L. (1967) Contribution à la faune du Congo (Brazzaville). Mission A. Villiers et A. Descarpentries. L. Orthoptères, Grylloidea. Bulletin de Institut Français d'Afrique noire, XXIX série A, No. 2 : 758-776.

Dajoz, R. (1985) Précis d'écologie. Ed. Dunod, Paris, 505 pp.

Desutter, L. (1987) Structure et évolution du complexe phallique des Gryllidea (Orthoptera) et classification des genres néotropicaux de Grylloidea. $1^{\text {re }}$ partie. Annales de la Société entomologique de France, New Series, 23, 213-239.

Desutter-Grandcolas, L. (2003) Phylogeny and the evolution of acoustic communication in extant Ensifera (Insecta, Orthoptera). Zoologica Scripta, 32, 525-561. http://dx.doi.org/10.1046/j.1463-6409.2003.00142.x

Desutter-Grandcolas, L., Hugel, S., Goutte, S. \& Robillard, T. (2018) Reflections on the growing use of sounds in systematics and synecology: why an acoustic signal cannot become an onomatophore. Bionomina, 13, 28-36.

https://doi.org/10.11646/bionomina.13.1.2. ISSN 1179-7657.

Desutter-Grandcolas, L., Jacquelin, L., Hugel, S., Boistel, R., Garrouste, R., Henrotay, M., Warren, B. H., Chintauan-Marquier, I. C., Nel P., Grandcolas, P. \& Nel, A. (2017) 3-D imaging reveals four extraordinary cases of convergent evolution of acoustic communication in crickets and allies (Insecta). Scientific Reports, 7: 7099. 9p.

https://doi.org/10.1038/s41598-017-06840-6. 
Gockowski, J.J. (1996) Quelques données de l'enquête agricole dans les villages de recherche. Programme EPHTA en collaboration avec l'IRAD/ASB : IITA-Yaoundé, Cameroun.

Gorochov, A. V. (1983) New genera and species of crickets of the subfamily Gryllinae (Orthoptera,Gryllidae) from Africa. Zoologichesky Zhumal 62: 951-954. 4p.

Gorochov, A. V. (1990) Ensifera from tropics and subtropics (Russian). Revue entomologique de l'URSS. 69(4): 820. 15p.

IUSS Working Group WRB. (2015) Global baseline for resources in soils 2014, Update 2015. International soil classification system for name the soils and create legends for soil maps. Report on soil resources of the world No. 106. FAO, Rome. 216 pp.

Kekeunou, S., Weise, S., Messi, J. \& Tamò, M. (2006) Farmers' perception on the importance of variegated grasshopper (Zonocerus variegatus (L.)) in the agricultural production systems of the humid forest zone of Southern Cameroon. Journal of Ethnobiology and Ethnomedicine. $2: 17$. https://doi.org/10.1186/1746-4269-2-17.

Orthoptera Species File online (Version 5.0/5.0). http://orthoptera.speciesfile.org/

Otte, D. (1985) African crickets (Gryllidae: Gryllinae).7. The genus Cryncus Gorochov. Proceedings of the Academy of Natural Sciences of Philadelphia.137: 129-142.

Oumarou Ngoute, C., Kekeunou, S., Lecoq, M., Nzoko Fiemapong, A.R., Um Nyobe, P.C.A. \& Bilong Bilong, C.F. (2020) Effect of anthropogenic pressure on grasshopper (Orthoptera: Acridomorpha) species diversity in three forests in southern Cameroon. Journal of Orthoptera Research 29 (1), 25-34.

R Core Team (2017) R: A language and environment for statistical computing. R Foundation for Statistical Computing, Vienna, Austria. URL https://www.R-project.org/.

Robain, H. (1998) Presentation of the soils of South Cameroon. Organization and implementation at the scale of the landscape unit. ORSTOM, pp. 134-142.

Santoir, C. \& Bopda, A. (1995) Atlas régional Sud-Cameroun. Orstom/Minrest, Paris/Yaoundé. http://www.documentation.ird.fr/hor/fdi:010004189. 53 pp.

Simeu-Noutchom, A., Kekeunou, S., Wandji, A.C., Mbadjoun Nzike, M., Oumarou Ngoute, C., Mbezele Messi, N. B. \& Tamesse, J. L. (2020) Gryllotalpa weisei SimeuNoutchom \& Kekeunou sp. nov. and the first record of Gryllotalpa microptera (Chopard 1939) (Orthoptera, Gryllotalpidae) from Cameroon with redescription of the species. Zootaxa 4763 (1) : 061-072. https://doi.org/10.11646/zootaxa.4763.1.5. ISSN 1175-5334.

Suchel, J.B. (1988) Les régions climatiques du Cameroun. Les climats du Cameroun. Thèse de Doctorat d'Etat, Université de Saint-Etienne (France), 4: 1188 pp.

Westphal, E., Embrechts, J., Mbouemboue, P., Mouzong-Boyomo \& Westphal-Stevels, J.M.C. (1981) L'agriculture autochtone au Cameoun Miscellaneous papers 20: Landbouwhogescool, Wageningen the Netherlans.175 pp. 
Table 1: Characteristics of the Benchmark village blocks (modified from Gockowski, 1996)

\begin{tabular}{lccc}
\hline $\begin{array}{l}\text { Characteristics of the village blocks of } \\
\text { the Benchmark }\end{array}$ & \multicolumn{3}{c}{ Sampling localities } \\
\cline { 2 - 4 } & $\begin{array}{c}\text { Ongot (Yaoundé } \\
\text { bloc) }\end{array}$ & $\begin{array}{c}\text { Zamakoé } \\
\text { (Mbalmayo bloc) }\end{array}$ & $\begin{array}{c}\text { Engout'Adjap (Ebolowa } \\
\text { bloc) }\end{array}$ \\
\hline Administrative divisions & Mefou and Akono & Nyong and So'o & Mvilla \\
\hline Level of forest cover degradation & Degraded & Less degraded & Almost not degraded \\
\hline Average age of fallows & 3.9 years & 5.4 years & 7.5 years \\
\hline Population density (inhabitants $\left./ \mathrm{km}^{2}\right)$ & $14-88 \mathrm{hab} / \mathrm{km}^{2}$ & $10-41 \mathrm{hab} / \mathrm{km}^{2}$ & $2-15 \mathrm{hab}^{2} \mathrm{~km}^{2}$ \\
\hline Altitude (m) & 810 & 657 & 593 \\
\hline Latitude (North) & $03^{\circ} 51^{\prime}$ & $03^{\circ} 33^{\prime}$ & $02^{\circ} 42^{\prime}$ \\
\hline Longitude (East) & $011^{\circ} 25^{\prime}$ & $011^{\circ} 31^{\prime}$ & $011^{\circ} 03^{\prime}$ \\
\hline
\end{tabular}

Table 2. Cryncus camerounensis sp. nov. measurements in millimeters: average \pm standard error (minimum-maximun) number of specimens studied

\begin{tabular}{|c|c|c|c|c|}
\hline Feature & Male & Female & t Value & P Value \\
\hline BL & $\begin{array}{l}13.11 \pm 0.76 \\
(11.2-14.84) 4\end{array}$ & $\begin{array}{l}13.25 \pm 0.47 \\
(10.72-16.3) 10\end{array}$ & 0.16 & 0.87 \\
\hline PL & $\begin{array}{l}2.36 \pm 0.04 \\
(2.29-2.46) 4\end{array}$ & $\begin{array}{l}2.51 \pm 0.05 \\
(2.27-2.88) 10\end{array}$ & 1.60 & 0.14 \\
\hline PW & $\begin{array}{l}3.67 \pm 0.03 \\
(3.61-3.74) 4\end{array}$ & $\begin{array}{l}3.61 \pm 0.07 \\
(3.31-3.95) 10\end{array}$ & 0.51 & 0.62 \\
\hline FWL & $\begin{array}{l}6.84 \pm 0.34 \\
(6.14-7.6) 4\end{array}$ & $\begin{array}{l}3.45 \pm 0.12 \\
(2.72-3.98) 10\end{array}$ & 11.92 & $5.20 \times 10^{-08}$ \\
\hline ML & $\begin{array}{l}2.71 \pm 0.08 \\
(2.53-2.92) 4\end{array}$ & I & l & l \\
\hline MW & $\begin{array}{l}1.58 \pm 0.02 \\
(1.53-1.62) 4\end{array}$ & I & l & I \\
\hline CL & $\begin{array}{l}6.01 \pm 0.67 \\
(5.34-6.68) 2\end{array}$ & $\begin{array}{l}6.88 \pm 0.41 \\
(5.1-8.78) 10\end{array}$ & 0.88 & 0.40 \\
\hline FL & $\begin{array}{l}9.60 \pm 0.27 \\
(8.96-10.12) 4\end{array}$ & $\begin{array}{l}9.60 \pm 0.20 \\
(9.05-10.93) 10\end{array}$ & 0.05 & 0.96 \\
\hline FW & $\begin{array}{l}3.09 \pm 0.10 \\
(2.84-3.32) 4\end{array}$ & $\begin{array}{l}3.31 \pm 0.04 \\
(3.14-3.61) 10\end{array}$ & 2.32 & 0.04 \\
\hline TL & $\begin{array}{l}5.93 \pm 0.10 \\
(5.68-6.16) 4\end{array}$ & $\begin{array}{l}6.94 \pm 0.20 \\
(5.83-7.62) 10\end{array}$ & 3.42 & 0.0045 \\
\hline OL & l & $\begin{array}{l}10.52 \pm 0.32 \\
(7.81-11.37) 10\end{array}$ & & I \\
\hline$\frac{\text { FWL }}{\text { PL }}$ & $\begin{array}{l}2.90 \pm 0.12 \\
(2.68-3.13) 4\end{array}$ & $\begin{array}{l}1.38 \pm 0.05 \\
(1.2-1.65) 10\end{array}$ & 14.2 & $7.16 \times 10^{-09}$ \\
\hline$\frac{\text { ML }}{\text { MW }}$ & $\begin{array}{l}1.71 \pm 0.07 \\
(1.58-1.91) 4\end{array}$ & I & l & l \\
\hline$\frac{\text { CL }}{\text { FL }}$ & $\begin{array}{l}0.61 \pm 0.04 \\
(0.57-0.66) 2\end{array}$ & $\begin{array}{l}0.72 \pm 0.04 \\
(0.55-0.95) 10\end{array}$ & 1 & 0.34 \\
\hline$\underline{\mathrm{OL}}$ & / & $1.1 \pm 0.03$ & I & I \\
\hline
\end{tabular}


Legend: $\mathrm{t}$ Value resulting from the parametric test ( $\mathrm{t}$-student). $\mathrm{P}$ Value is the probability value. / Missing or absent data.

Table 3. Cryncus desutterae sp. nov. measurements in millimeters: average \pm standard error (minimummaximun) number of specimens studied

\begin{tabular}{|c|c|c|}
\hline Feature & Male & Female \\
\hline BL & 12.09 & $\begin{array}{l}12.2 \pm 1.06 \\
(11.14-13.26) 2\end{array}$ \\
\hline PL & 1.57 & $\begin{array}{l}2.21 \pm 0.19 \\
(2.02-2.4) 2\end{array}$ \\
\hline PW & 2.7 & $\begin{array}{l}3.13 \pm 0.05 \\
(3.08-3.18) 2\end{array}$ \\
\hline FWL & 7.49 & $\begin{array}{l}6.38 \pm 0.76 \\
(5.62-7.14) 2\end{array}$ \\
\hline ML & 2.67 & I \\
\hline MW & 1.69 & I \\
\hline CL & 0 & $(5.47) 1$ \\
\hline FL & 7.21 & $\begin{array}{l}7.42 \pm 0.10 \\
(7.32-7.53) 2\end{array}$ \\
\hline FW & 2.68 & $\begin{array}{l}2.33 \pm 0.02 \\
(2.31-2.36) 2\end{array}$ \\
\hline TL & 4.99 & $\begin{array}{l}5.31 \pm 1.11 \\
(4.2-6.42) 2\end{array}$ \\
\hline $\mathbf{O L}$ & 0 & $\begin{array}{l}8.43 \pm 1.57 \\
(6.86-10.01) 2\end{array}$ \\
\hline$\frac{\text { FWL }}{\text { PL }}$ & 4.77 & $\begin{array}{l}2.87 \pm 0.09 \\
(2.78-2.97) 2\end{array}$ \\
\hline$\frac{\text { ML }}{\mathrm{MW}}$ & 1.58 & l \\
\hline$\frac{\text { CL }}{\text { FL }}$ & 0 & $(0.73) 1$ \\
\hline$\frac{\mathrm{OL}}{\mathrm{FL}}$ & 0 & $\begin{array}{l}1.13 \pm 0.2 \\
(0.94-1.33) 2\end{array}$ \\
\hline
\end{tabular}

Legend: / Missing or absent data.

TABLE 4. Frequencies of occurrence of Cryncus camerounensis sp. nov. and Cryncus desutterae sp. nov. as a function of the types of vegetation and localities.

\begin{tabular}{lllll}
\hline Species & Localities & \multicolumn{2}{c}{ Habitats } & Total \\
\cline { 3 - 4 } & & Forests & Fallows & \\
\hline Cryncus & Engout'Adjap & $1(5.26 \%)$ & 0 & $1(5.26 \%)$ \\
\cline { 2 - 5 } camerounensis & Ongot & $1(5.26 \%)$ & 0 & $1(5.26 \%)$ \\
\cline { 2 - 5 } & Zamakoe & $3(15.80 \%)$ & $1(5.26 \%)$ & $4(21.06 \%)$
\end{tabular}




\begin{tabular}{cllll}
\hline \multicolumn{1}{c}{ Total } & & $5(26.32 \%)$ & $1(5.26 \%)$ & $6(31.58 \%)$ \\
\hline \multirow{2}{*}{$\begin{array}{c}\text { Cryncus } \\
\text { desutterae }\end{array}$} & Engout'Adjap & 0 & 0 & 0 \\
\cline { 2 - 5 } & Ongot & 0 & $2(10.52 \%)$ & $2(10.52 \%)$ \\
\cline { 2 - 5 } & Zamakoe & 0 & $1(5.26 \%)$ & $1(5.26 \%)$ \\
\hline \multicolumn{1}{c}{ Total } & & 0 & $3(15.78 \%)$ & $3(15.78 \%)$ \\
\hline
\end{tabular}

TABLE 5. Frequencies of occurrence of Cryncus camerounensis sp. nov. and Cryncus desutterae sp. nov. depending on the capture methods and localities.

\begin{tabular}{lllll}
\hline \multirow{2}{*}{ Species } & Localities & \multicolumn{2}{c}{ Capture method } & \multirow{2}{*}{ Total } \\
\cline { 3 - 4 } & & Pitfalls & Quadrats & \\
\hline \multirow{2}{*}{$\begin{array}{c}\text { Cryncus } \\
\text { camerounensis }\end{array}$} & Engout'Adjap & $1(5.26 \%)$ & 0 & $1(5.26 \%)$ \\
\cline { 2 - 5 } & Ongot & $1(5.26 \%)$ & 0 & $1(5.26 \%)$ \\
\cline { 2 - 5 } Total & Zamakoe & $3(15.80 \%)$ & $1(5.26 \%)$ & $4(21.06 \%)$ \\
\hline Cryncus & & $5(26.32 \%)$ & $1(5.26 \%)$ & $6(31.58 \%)$ \\
desutterae & Engout'Adjap & 0 & 0 & 0 \\
\cline { 2 - 5 } & Ongot & $2(10.52 \%)$ & 0 & $2(10.52 \%)$ \\
\cline { 2 - 5 } & Zamakoe & $1(5.26 \%)$ & 0 & $1(5.26 \%)$ \\
\hline \multicolumn{1}{c}{ Total } & & $3(15.78 \%)$ & 0 & $3(15.78 \%)$ \\
\hline
\end{tabular}




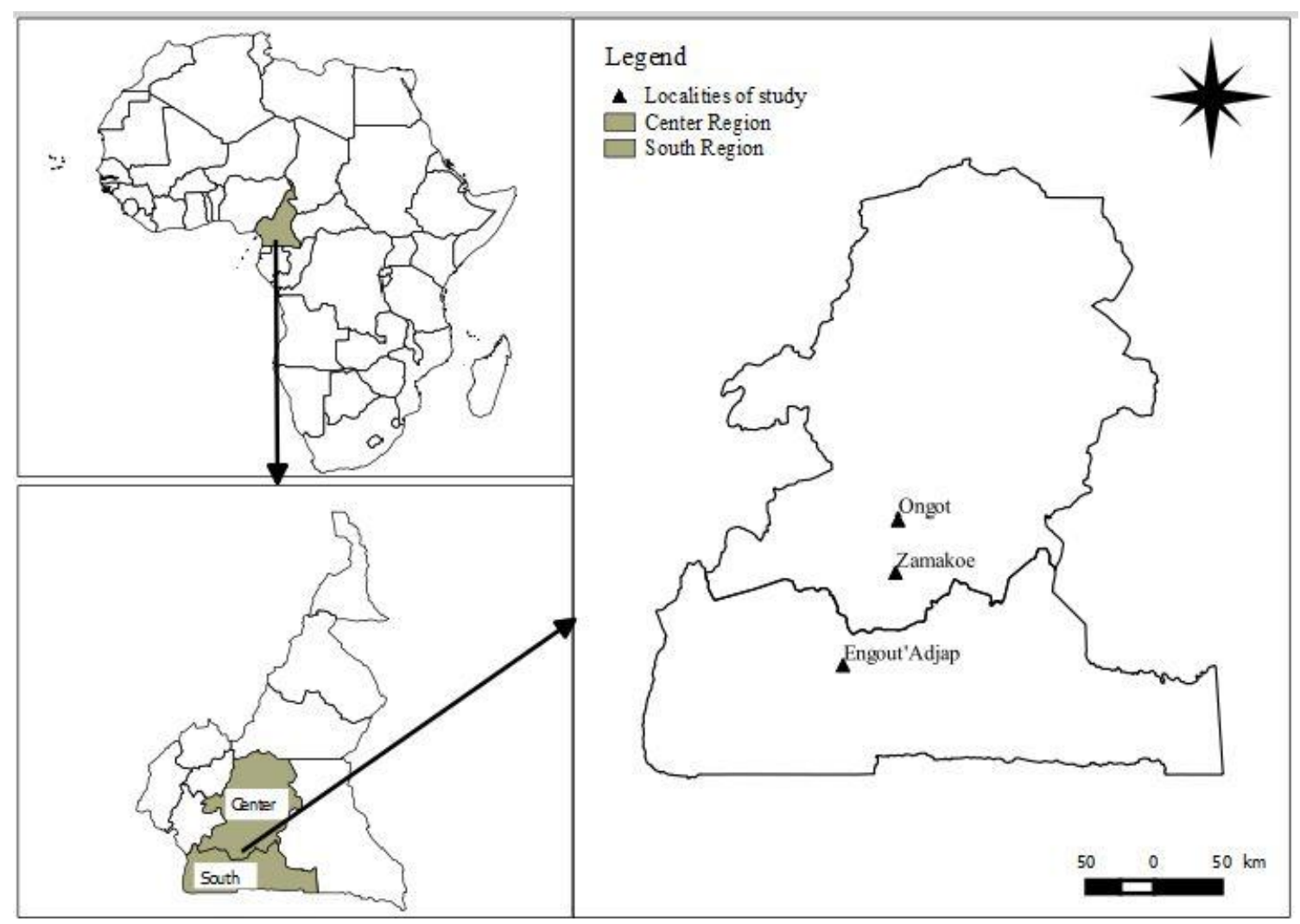

Figure 1. Location of the sampling localities. 

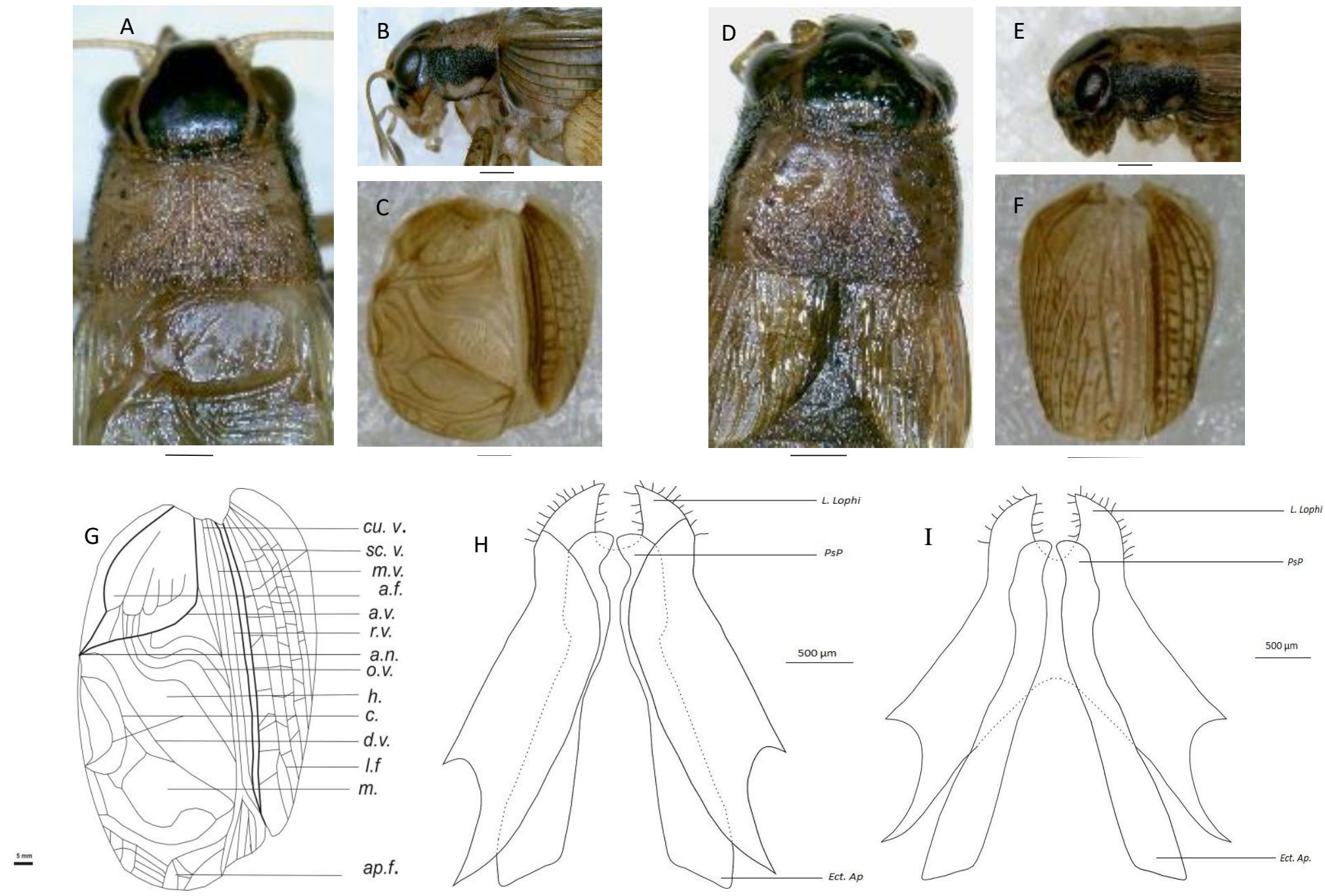

Figure 2. Morphology of Cryncus camerounensis sp. nov.: (A) male head and pronotum, (B) male lateral view of head and pronotum, (C) male forewing, (D) female head and pronotum, (E) female lateral view of head and pronotum, $(\mathrm{F})$ female fore wing, $(\mathrm{G})$ male forewing drawing, $(\mathrm{H})$ male genitalia drawing in dorsal view, (I) male genitalia drawing in ventral view. Scale bars: A: $7 \mathrm{~mm} ; \mathrm{B}$, C, E: $5 \mathrm{~mm} ; \mathrm{D}, 8 \mathrm{~mm} ; \mathrm{F}, 11 \mathrm{~mm} ; \mathrm{G}, 5 \mathrm{~mm} ; \mathrm{H}, \mathrm{I}, 500 \mu \mathrm{m}$. 

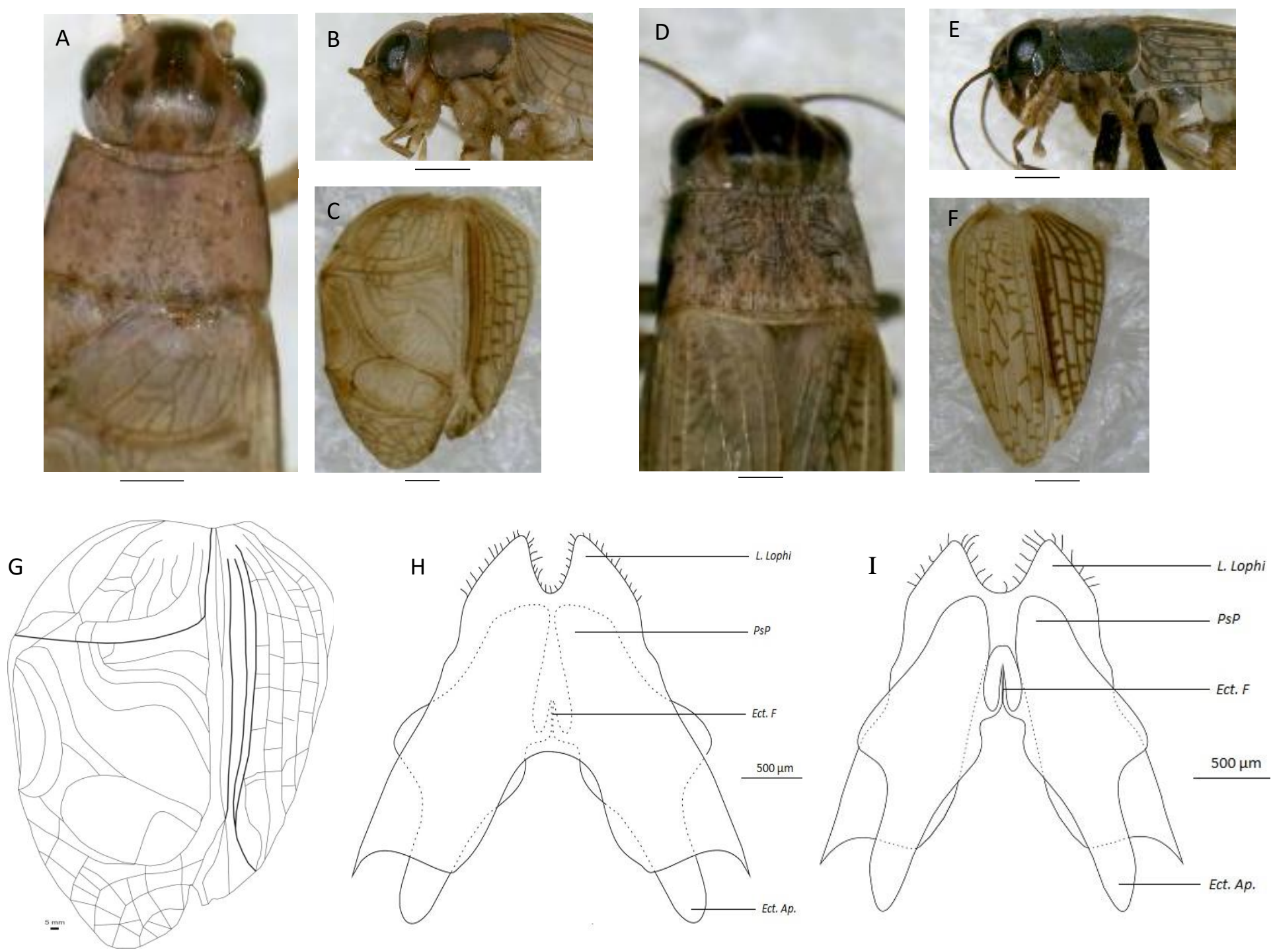

Figure 3. Morphology of Cryncus desutterae sp. nov.: (A) male head and pronotum, (B) male lateral view of head and pronotum, (C) male fore wing, (D) female head and pronotum, (E) female lateral view of head and pronotum, $(\mathrm{F})$ female forewing, $(\mathrm{G})$ male forewing drawing, $(\mathrm{H})$ male genitalia drawing in dorsal view, (I) male genitalia drawing in ventral view. Scale bars: A, $9 \mathrm{~mm}$; , $8 \mathrm{~mm}$;C, 5 mm; D, F: 7 mm;E, 6 mm ; H, I, $500 \mu \mathrm{m}$. 


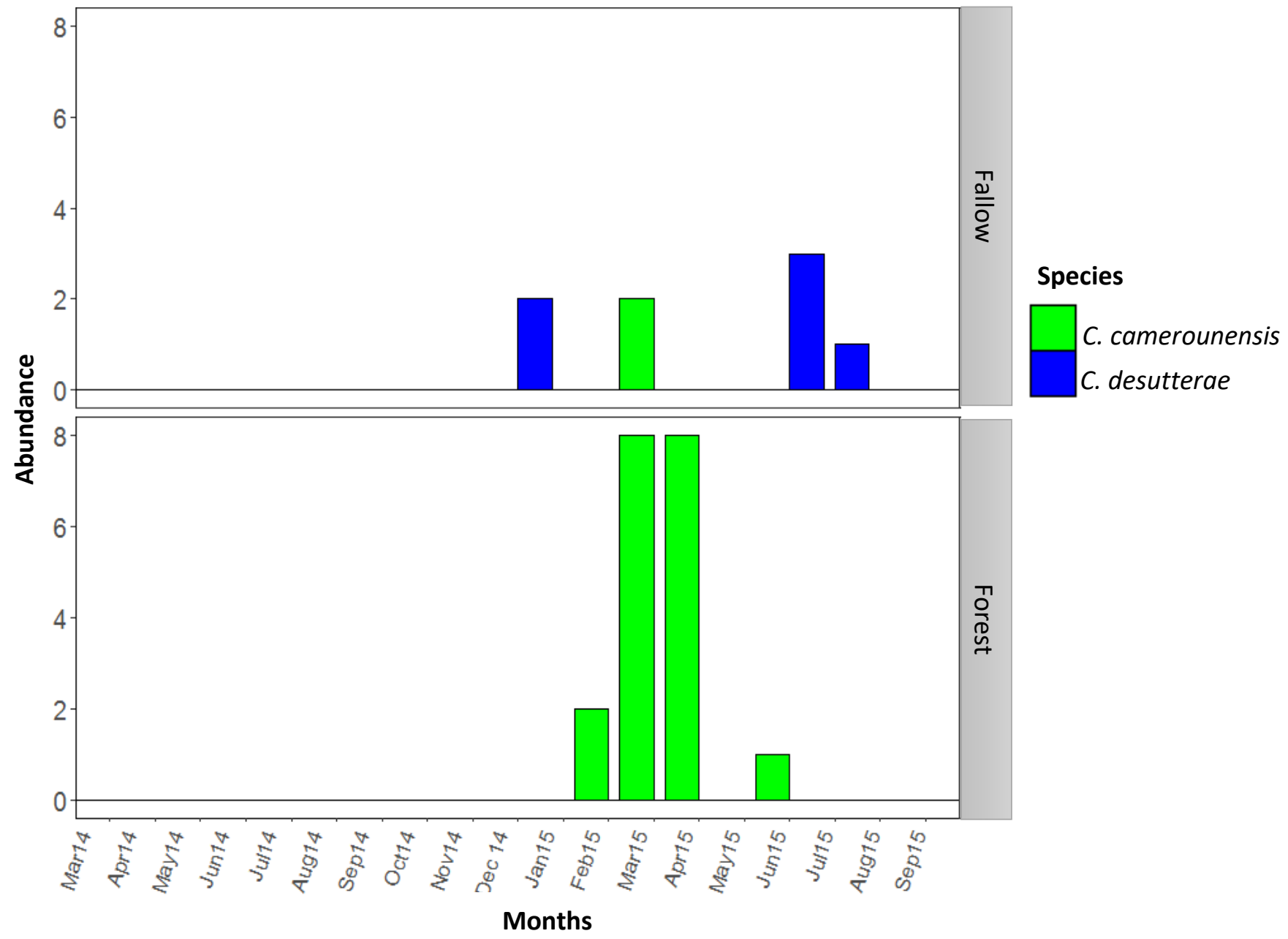

Figure 4. Numeric temporal fluctuations of Cryncus camerounensis sp. nov. and Cryncus desutterae sp. nov. in forests and fallows of southern Cameroon plateau. 
Legend

- Distribution of African species of the genus Cryncus

1. C. apricus

2. C. saussurei

3. C. olsuflevi

4. C. bifasciatus

5. C. massarti

6. C. notabilis

7. C. dmitrievi

8. C. scenicus

9. C. duplicatus

10. C. superciliosus

11. C. pugu

12. C. mombo

13. C. grumeti

14. C. agilis

15. C. alternatus

16. C. impiger

17. C. sagalus

18. C. matuga

19. C. gambelae

20. C. illubabori

21. C. medvedevi

22. C. pulchellus

23. C. rybalovi

24. C. camerounensis

25. $C$. desutterae
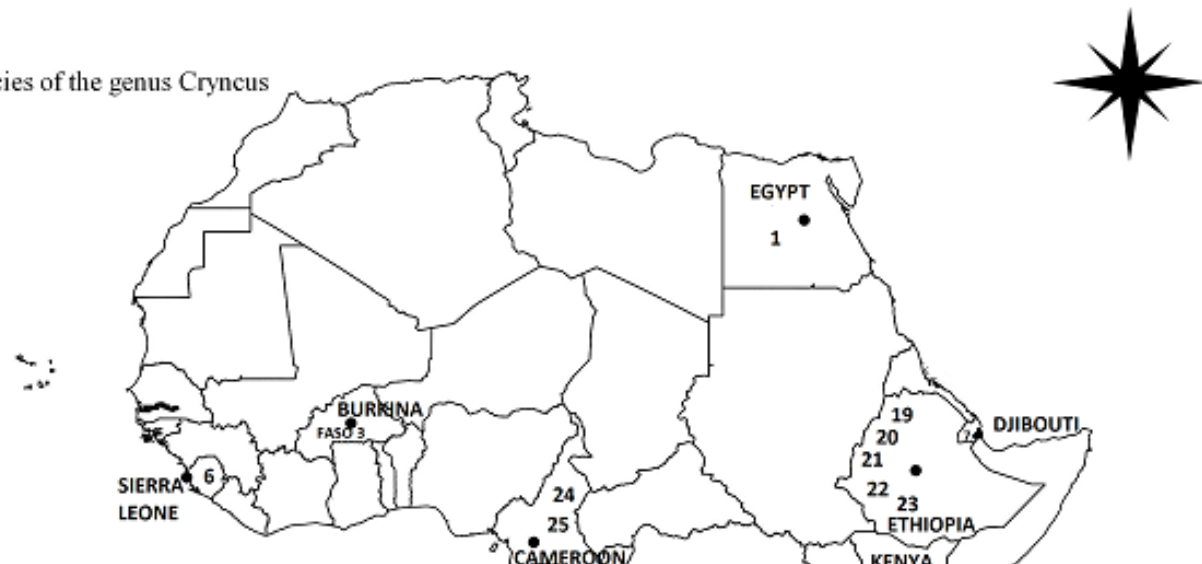

Figure 5. Distribution map of African species of the genus Cryncus. 